Кравщов О.В., к.хім.н., доч., ДРІДУ НАДУ при Президентові Украӥни, м. Дніпро, ORCID: 0000-0002-8027-1796,

Кравцова T.В., к.т.н., дои., ДРІДУ НАДУ при Президентові України, м. Дніпро, ORCID: 0000-0002-5138-3799,

Лащенко О.В., к.держ.упр., доч., ДРІДУ НАДУ при Президентові України, м. Дніпро, ORCID: 0000-0002-0267-4258

Kravtsov O., PhD in Chemical Sciences, associate professor, Associate professor of Information Technologies and Information Systems department of Dnipropetrovsk regional institute for public administration, National academy for public administration under the President of Ukraine, Dnipro,

Kravtsova T., PhD in Technical Science), associate professor, Associate professor of Management and project management department of Dnipropetrovsk regional institute for public administration, National academy for public administration under the President of Ukraine, Dnipro,

Lashenko O., PhD in Public Administration, associate professor, Associate professor of Management and project management department of Dnipropetrovsk regional institute for public administration, National academy for public administration under the President of Ukraine, Dnipro

\title{
ДЕРЖАВНА ПОЛІТИКА В СФЕРІ ВИЩОЇ ОСВІТИ УКРАЇНИ В УМОВАХ ЦИФРОВІЗАЦІЇ
}

\section{STATE POLICY IN THE FIELD OF HIGHER EDUCATION OF UKRAINE IN THE CONDITIONS OF DIGITALIZATION}

Стимулювання та координування розвитку вищої освіти є пріоритетним напрямком діяльності держави, а формування якісної системи надання освітніх послуг є однією із пріоритетних сфер державного управління. Реформування сфери вищої освіти України, потреба інтеграчії з глобальним інформаційним відкритим освітнім простором вимагає забезпечення цифрової трансформації закладів вищої освіти та дослідження здобутків і перспектив.

У статті розкрито сутність та етапи розвитку вищої освіти в Украӥні. Виокремлені основні тенденції та сучасні виклики освітньої політики на сучасному етаni. Узагальнено, що сучасними тенденціями розвитку вищої освіти Украйни є навчання впродовж життя, мобільність і розвиток інтернаціоналізації, гнучкість навчальних програм, цифровізаџія, збільшення частки дистанџійного навчання, креативне навчання, електронна наука тощо. 
Розкрито особливості ичифровізації вищої освіти в умовах пандемії, проблеми та напрями удосконалення діяльності органів державного управління у даній сфері. У першу чергу потрібно забезпечити: ичифровізачію внутрішніх процесів/сервісів 3ВО; створення системи циифрового маркетингу, яка б забезпечувала: організацію взаємодії університету з абітурієнтами та їхніми батьками, випускниками і роботодавцями; постійний моніторинг репутації університету та формування позитивного іміджу ЗВО; стимулювання створення нових цуифрових спільнот та інновацій на всіх етапах освітнього циклу; створення системи циифрової взаємодії з абітурієнтами та студентами; проведення заходів, направлених на подолання циифрової нерівності.

Реалізачія потенціалу $3 B O$ за рахунок ичифрової трансформації можлива лише за наявності дієвої державної політики, щзо розроблена, реалізується та удосконалюється згідно із умовами сьогодення та спрямована на посилення конкурентоспроможності та підвищення якості освіти.

Ключові слова: вищза освіта, наука, реформування, європейський простір, и̧ифровізація.

Stimulating and coordinating the development of higher education is a priority of the state, and the formation of a quality system of educational services is one of the priority areas of public administration. Reforming the sphere of higher education in Ukraine, the need for integration with the global information open educational space requires ensuring the digital transformation of higher education institutions and the study of achievements and prospects.

The article reveals the essence and stages of development of higher education in Ukraine. The main trends and current challenges of educational policy at the present stage are highlighted. It is generalized that the current trends in the development of higher education in Ukraine are lifelong learning, mobility and development of internationalization, flexibility of curricula, digitalization, increasing the share of distance learning, creative learning, e-science and more.

Peculiarities of digitalization of higher education in the conditions of a pandemic, problems and directions of improvement of activity of public administration bodies in this sphere are revealed. First of all it is necessary to provide: digitalization of internal processes / services of Higher education institutions; creation of a digital marketing system that would provide: organization of interaction of the university with entrants and their parents, graduates and employers; constant monitoring of the university's reputation and formation of a positive image of the Free Economic Zone; stimulating the creation of new digital communities and innovations at all stages of the educational cycle; creating a system of digital interaction with entrants and students; taking measures to address digital inequality.

Realization of the potential of higher education institutions through digital transformation is possible only if there is an effective state policy that is developed, implemented and improved in accordance with today's conditions and aimed at strengthening competitiveness and improving the quality of education.

Key words: higher education, science, reforming, European space, digitalization.

Постановка проблеми. В умовах сталого розвитку однією із пріоритет- 
них сфер державного управління є формування якісної системи надання освітніх послуг, оскільки вища освіта в Україні є основою інтелектуального та матеріального благополуччя держави. Вона спрямована на забезпечення фундаментальної наукової та прикладної підготовки професіоналів, які мають формулювати темпи та рівень науково-технічного прогресу, соціально-економічного і культурного розвитку, а також забезпечення національних інтересів, зміцнення авторитету і конкурентоспроможності держави на міжнародній арені. Здобута вища освіта стає все більш обов'язковою умовою для працевлаштування фахівців відповідно до вимог ринку праці.

Сьогодні вища освіта розвивається як відкрита державно-суспільна система. Глобальні процеси всесвітньої економічної, політичної та культурної інтеграції України у світовий простір змінюють роль вищої освіти в суспільстві, адже ринкові принципи стають важливою умовою для ііі реформування та функціонування. Зростає вплив ринкових відносин, що проявляється у посиленні конкуренції (на національному та міжнародному рівнях) за талановиту молодь, викладачів та науковців, за фінансові ресурси. Цифровізація всіх сфер життєдіяльності висуває нові складні виклики. Маркетизація вимагає від вищої освіти надавати якісні освітні послуги та готувати фахівців відповідно до потреб роботодавців [6]. Традиційна модель університету не може конкурувати 3 викликами, що стоять перед вищою освітою: навчання впродовж життя, мобільність і розвиток інтернаціоналізації, гнучкість навчальних програм, впровадження ITскладника в навчальні програми та наукові студії, креативне навчання, компетенції XXI століття, електронна наука тощо.

Зважаючи на це, особливої актуальності набуває питання державної політики у сфері вищої освіти в Україні, оскільки стимулювання та координування іiі розвитку є пріоритетним напрямком діяльності держави та відповідно іiі органів.

Аналіз останніх досліджень і публікацій. Питання реалізації державної політики у сфері вищої освіти, а також питання ії цифровізації розглядали такі науковці, як В. Вакуленко, С. Домбровська Н. Мосьпан, М. Перекрест, В. Петриків, В. Тєтєрєв О. Тоцька, У. Ткаченко, Л. Шевченко та ін. Разом з тим, стрімке реформування вітчизняної освітньої сфери, поява нових тенденцій як в Україні, так і за кордоном, вимагає проведення нових комплексних досліджень у цій сфері.

Метою статті $\epsilon$ дослідження сутності, етапів розвитку та сучасного стану державної політики у сфері вищої освіти України в умовах цифровізації.

Виклад основного матеріалу. Розвиток сучасної вітчизняної вищої освіти розпочався у 2005 році, коли Україна підписала Болонську декларацію і заявила про бажання працювати у європейському освітньому просторі. Щоб досягти європейських стандартів, українська освіта повинна була здійснити конкретні кроки, передбачені Болонською декларацією, а саме: увести двоциклове навчання для одержання першого та другого академічного ступеня; запровадити у всіх національних системах освіти систему обліку трудомісткості навчальної 
роботи в кредитах; забезпечити контроль якості освіти через організацію акредитаційних агентств, незалежних від національних урядів і міжнародних організацій; істотний розвиток мобільності студентів; орієнтація на кінцевий результат - забезпечення працевлаштування випускників; залучення на навчання в Європі більшої кількості студентів через забезпечення привабливості європейської системи вищої освіти; навчання впродовж життя; автономність вищих навчальних закладів і студентське самоврядування; забезпечення позитивного іміджу європейської системи вищої освіти та навчання докторантів як запровадження третього циклу підготовки [5].

Проте, з моменту підписання Болонської декларації вища освіта зазнала значних змін. Сучасне десятиліття модернізації вітчизняної системи вищої освіти характеризується удосконаленням впровадження Болонського процесу та зростанням ринкової орієнтації закладів вищої освіти (3ВО) [6].

Важливим кроком у процесі реформування вищої освіти стало прийняття Законів України «Про вищу освіту» у 2014 р. а також Національної стратегії розвитку освіти в Україні на період до 2021 року (далі - НСРО), яка конкретизує основні шляхи реалізації концептуальних ідей і поглядів розвитку освіти, визначених Національною доктриною розвитку освіти (далі - НДРО) [15].

Закон України «Про вищу освіту» встановлює основні правові, організаційні, фінансові засади функціонування системи вищої освіти, створює умови для посилення співпраці державних органів і бізнесу із закладами вищої освіти (ЗВО) на принципах автономії 3ВО, поєднання освіти з наукою та виробництвом $з$ метою підготовки конкурентоспроможного людського капіталу для високотехнологічного та інноваційного розвитку країни, самореалізації особистості, забезпечення потреб суспільства, ринку праці та держави у кваліфікованих фахівцях [5]. У даному законі розкрито сутність основних термінів: вища освіта, зміст вищої освіти, зміст навчання, стандарт вищої освіти, вищий навчальний заклад; надано правовий статус вищим навчальним закладам, описано рівні акредитації закладів вищої освіти, сформовано принципи управління вищими навчальними закладами тощо.

Згідно із Законом України «Про вищу освіту» - «вища освіта це сукупність систематизованих знань, умінь і практичних навичок, способів мислення, професійних, світоглядних і громадянських якостей, морально-етичних цінностей, інших компетентностей, здобутих у закладі вищої освіти (науковій установі) у відповідній галузі знань за певною кваліфікацією на рівнях вищої освіти, що за складністю $є$ вищими, ніж рівень повної загальної середньої освіти» [5].

Законом гарантується право на вищу освіту незалежно від віку, громадянства, місця проживання, статі, кольору шкіри, соціального і майнового стану, національності, мови, походження, стану здоров'я, ставлення до релігії, наявності судимості, а також від інших обставин (ст. 4). Одним із принципів державної політики у сфері вищої освіти визначено сприяння сталому розвитку суспільства шляхом підготовки конкурентоспроможного людського капіталу та створення умов для освіти протягом життя (ст. 3) [5]. 
Відповідно до Закону підготовка фахівців з вищою освітою здійснюється за відповідними освітніми чи науковими програмами на таких рівнях вищої освіти: початковий рівень (короткий цикл) вищої освіти; перший (бакалаврський) рівень; другий (магістерський) рівень; третій (освітньо-науковий/освітньотворчий) рівень (ст. 5).

Управління у сфері вищої освіти у межах своїх повноважень здійснюється: Кабінетом Міністрів України; центральним органом виконавчої влади у сфері освіти і науки; галузевими державними органами, до сфери управління яких належать заклади вищої освіти; органами місцевого самоврядування, до сфери управління яких належать заклади вищої освіти; Національною академією наук України та національними галузевими академіями наук; засновниками закладів вищої освіти; органами громадського самоврядування у сфері вищої освіти і науки та Національним агентством із забезпечення якості вищої освіти [5].

Розвиток вищої освіти залежить від багатьох чинників, серед яких врахування досягнень і позитивів минулого, що викликає необхідність дослідження основних здобутків та історичні етапи розвитку вищої освіти в Україні.

Однак, серед науковців єдиної точки зору щодо визначення етапів розвитку вищої освіти в Україні на сьогодні не існує. Окремі дослідники простежують розвиток вищої освіти в Україні, починаючи з освітньої системи Київської Русі, яка ще не мала державного підпорядкування та забезпечувалася церквою. Інші дослідники акцентують увагу на розвиток системи освіти за радянських часів та в умовах незалежної України.

Так, на думку В. М. Вакуленко в історії розвитку вищої освіти Україні умовно на основі історичних подій можна виділити п'ять етапів. Перший (1576-1805 рр.) - зародження вищої освіти, поява перших навчальних центрів; II етап (1805-1850) організаційний - виникнення університетів на українській території, що перебувала у складі Російської та Австро-Угорської імперій, удосконалення змісту освіти; III етап (1850-1917) - спеціалізація вищих навчальних закладів з урахуванням сучасних перетворень в промисловості; IV етап (1917-1991) - радянський період розвитку вищої освіти: зростання кількості вищих навчальних закладів і чисельності студентів, введення заочної форми навчання, покращення навчально-методичного забезпечення та якості навчання студентів; V етап (1991 - до сьогодення) - утвердження незалежності України: реформування, децентралізація й демократизація вищої освіти, розширення прав вищих закладів освіти, надання академічної свободи у виборі форм і методів навчання, підвищення ролі самостійної роботи студентів, інтеграція у загальноєвропейську систему освіти [3].

У працях В. Петриків для періодизації вищої освіти використовується критерій рівня державного регулювання господарської діяльності вищих навчальних закладів, починаючи 3 радянських часів. Даний дослідник наводить чотири періоди розвитку вищої освіти в Україні, а саме:

I період - «пострадянський» розвиток законодавства України, основним 
завданням якого було формування нормативно-правової бази, що визначала б діяльність закладів вищої освіти на початку 90-х рр. ХХ ст.

II період - кінець 1991р.-1995 р., характеризується зниження фінансування закладів вищої освіти, появою та узаконенням приватних закладів, появою чітких рекомендацій щодо проведення акредитації вищих навчальних закладів.

III період - 1996-2000 pp., збагачення та розширення нормативноправової бази вищої освіти в Україні.

IV період - 32000 р. і до сьогодні, інтеграційні процеси та пошук нових підходів в організацій вищої освіти [9; 13].

На наш погляд, особливої уваги заслуговує періодизація вищої освіти, наведена У. Ю. Ткаченко, яка акцентує увагу на розвитку вищої освіти з моменту визнання незалежності України. Так, дана дослідниця в основу визначення періодів поклала критерії суспільно-політичних трансформацій, соціальноекономічних чинників та педагогічних концептів, i, як результат, виділила такі періоди:

I період (1991-2000 рр.) - становлення системи вищої освіти в Україні. Характеризується такими факторами, як проголошення незалежності України, національним піднесенням, соціально-економічними та політичними змінами, а також початком формування нормативно-правового забезпечення функціонування вищої освіти (створенням Міністерства освіти та прийняттям низки законів, які визначили нормативно-правове регулювання системи освіти.

II період (2000-2005 pp.) - розвиток у контексті ступневості и неперервності. Характеризується переходом вищої освіти на чотири ступені підготовки спеціалістів: молодший спеціаліст, бакалавр, спеціаліст та магістр.

III період (2005-2014 рр.) - розвиток у контексті реалї Болонської декларації. Характеризується інтеграційними процесами, підписанням Болонської декларації, яка засвідчила об'єднання освітніх систем у єдиний Загальноєвропейський простір вищої освіти.

IV період (2014-2019 рр.) - трансформація вищої освіти. Даний етап вимагає постійного удосконалення та розвитку усіх учасників освітнього процесу, а саме: підвищення рівня професіоналізму викладачів та підготовки студентів; модернізації змісту із врахування здобутків світової педагогічної думки; педагогіка партнерства; стимулювання до саморозвитку та самовдосконалення; забезпечення розвитку ключових і предметних компетентностей здобувачів освіти; мобільності та гнучкості вищої освіти; міжнародні освітні програми та продовження навчання за кордоном стають доступними для українців; активний обмін досвідом із зарубіжними колегами; інтеграція у міжнародний науковий простір; збагаченні активними формами та методами навчання; інтерактивні технології; розвиток особистісних характеристик і студентів, і викладачів: критичного мислення, творчості, ІКТ-компетентності; інформатизації освітнього процесу; застосування сучасних цифрових технологій для створення новітньої навчально-наукової експериментальної бази на основі перспективних досліджень та технологічних рішень; впровадження Інтернет ресурсів, хмарних тех78 
нологій в освіту [13].

Як бачимо, генеза вищої освіти України пройшла кілька важливих етапів розвитку, проте їх кількість однозначно не визначена. У процесі свого розвитку трансформація вищої освіти України набуває рис національної самоідентичності, прагнення до інтеграції в загальноєвропейську систему освіти, модернізації змістового наповнення, збагачення новими технологіями та інструментами.

Пандемічна криза COVID-19 призвела до прискорення трансформаційних процесів, які спричинили багато змін всіх аспектів життя, у тому числі - і в освітньому просторі, а також зумовила появу нових викликів для закладів вищої освіти та органів управління освітою як на місцевому, так і на національному рівні. Масове закриття 3ВО яскраво продемонструвало, що освітня спільнота недостатньою мірою готова до сучасних викликів дистанційної освіти [4].

Карантин суттєво вплинув на вищу освіту, змусивши ЗВО адаптуватися до нового формату освітніх послуг. Питання дистанційного навчання в контексті пандемії коронавірусу стають актуальними як ніколи раніше. Вища освіта в Україні не була готова до дистанційного навчання (онлайносвіти) у березні 2020 року, відчувши великий шок протягом першого тижня карантину. Реальність показала, що не всі заклади вищої освіти були технічно підготовлені. Також ЗВО стикалися з організаційними та психологічними проблемами. Українським закладам вищої освіти вдалося поступово забезпечити онлайн-освіту (з віртуальними заняттями включно) завдяки внутрішнім ресурсам (системи управління цифровим навчанням - Moodle, Neron) та зовнішнім освітнім програмам, платформам і ресурсам, рекомендованим ЮНЕСКО. Впровадження онлайн-навчання викликало нові проблеми у вищій освіті. 3 одного боку, це вимагає підвищення цифрової грамотності як викладачів (у першу чергу, літніх викладачів), так і студентів. 3 іншого боку, перехід на цифровий формат змушує ЗВО знаходити додаткові гроші для фінансування освітніх технологій та збільшення IT-фахівців [6]. Усе це вимагає від ЗВО розробляти та впроваджувати інноваційні рішення за досить короткий часовий проміжок, забезпечувати реалізацію онлайн-навчання за допомогою використання різноманітних веб-серверів, інтернет-платформ, месенджерів, інформаційних ресурсів та соціальних мереж. Загалом пандемія згенерувала значні структурні зміни у 3ВО, спричинені змінами потреб студентів, розвитком і поширенням інноваційних технологій навчання, зменшенням кількості іноземних студентів, а також закриттям, об'єднанням та реструктуризацією університетів через скорочення фінансування та кількості студентів, яка різко зменшується протягом останнього десятиліття [4].

Тому одним із основних завдань сьогодення $є$ забезпечення цифрової трансформації університетів, що буде відповідати вимогам та можливостям ринку, реалізує інтеграцію з глобальним інформаційним відкритим освітнім простором, який передбачає вільний доступ усіх учасників до світових цифрових ресурсів, задоволення освітніх потреб студентів в цифрових продуктах, а також ефективну е-комунікацію та е-співпрацю усіх учасників освітнього процесу [2]. 
Очевидно, що поняття «цифровізація вищої освіти» набагато ширше за обсягом i змістом за просте «впровадження сучасних інформаційнокомунікаційних технологій» в освітній процес університетів [1].

Згідно з Концепцією розвитку цифрової економіки та суспільства України на 2018-2020 роки «цифровізація» - це насичення фізичного світу електронноцифровими пристроями, засобами, системами та налагодження електроннокомунікаційного обміну між ними, що фактично уможливлює інтегральну взаємодію віртуального та фізичного, тобто створює кіберфізичний простір [10]. Концепція передбачає використання електронних учбових матеріалів, мультимедійно-наукових, інформаційних ресурсів у веб-павутині Інтернет [8].

Серед ключових завдань, які ставить перед собою Міністерство освіти і науки України на 2021 рік, одним з пріоритетних $є$ впровадження цифрової трансформації, для чого планується реалізувати наступні кроки:

- затвердити Концепцію цифрової трансформації освіти і науки України;

- забезпечити учасників освітнього процесу електронними освітніми ресурсами;

- створити умови для підвищення кваліфікації педагогічних працівників закладів освіти з інформаційно-цифрової компетентності;

- забезпечити функціонування програмно-апаратного комплексу «Автоматизований інформаційний комплекс освітнього менеджменту» (ПАК «AIKOM»);

- запустити інформаційну систему управління професійною (професійно-технічною) освітою (EMIS); (СДЕБО);

- модернізувати Єдину державну електронну базу 3 питань освіти

- створити онлайн-платформу для комунікації між учасниками інноваційного процесу («Наука та бізнес»);

- запустити проєкт SELFIE у пілотних школах і закладах професійної освіти - платформа для самооцінки закладами освіти стану своєї цифрової готовності;

- приєднатися до процесів створення та розбудови Свропейської хмари відкритої науки (EOSC);

- удосконалити та наповнювати контентом платформу «Всеукраїнська школа онлайн».

В сучасних умовах, основними стратегічними напрямами розвитку дистанційного формату навчання $є$ :

- розробка програмно-технічного забезпечення та зміцнення матеріальної бази ЗВО для впровадження нових технологій у вищій освіті;

- забезпечення ЗВО України широкосмуговим доступом до Інтернет; організація співпраці розробників програмних продуктів для дистанційного навчання, методистів дистанційної освіти і викладачів 3ВО для напрацювання стратегій застосування нових інформаційних технологій у дистанційному навчанні;

80 
- кадрове забезпечення дистанційного навчання, підготовка спеціалістів сфери дистанційної освіти з урахуванням сучасних тенденцій розвитку інформаційних та педагогічних технологій;

- розробка і поширення платформ з інтуїтивним не складним програмним інтерфейсом для створення дистанційних курсів;

- вирішення проблем цифрової нерівності;

- створення чи адаптація інформаційних технологій та електронних навчально-методичних розробок з підтримки нових технологій дистанційного навчання у ЗВО України [12].

Для відповіді на сучасні виклики університети мають перейти не тільки до цифрових інструментів у традиційному навчальному процесі, а й до повністю нових цифрових моделей навчання; розробити програми цифрової трансформації для забезпечення конкурентоспроможності освітньої, науково-дослідної та господарської діяльності на національному та світовому рівнях [16].

Українські університети постали перед низкою викликів, а саме:

- пошуком моделі цифровізації кожним закладом вищої освіти в межах визначеної автономії;

- необхідністю формування оптимальної структури закладу вищої освіти та поєднання складників цієї структури в ефективну систему, на основі якої і формується цифровий університет;

- поєднанням елементів інформаційно-комунікаційних технологій, що є в кожному університеті, у систему, на основі якої і формується цифровий університет, і технічних засобів навчання у дієві мережеві інструменти;

- визначенням ролі, завдань і видів діяльності для наукових, науковопедагогічних і педагогічних працівників такого університету;

- заміною традиційного «аудиторного» освітнього простору на віртуально-мережевий;

- пошуком відповідних освітнім завданням методів і прийомів дистанційного навчання;

- налагодженням ефективної комунікації усіх учасників освітнього процесу в мережевому середовищі [1].

Узагальнення світового досвіду вказує на те, що цифровізація вищої освіти повинна включати $[11 ; 16]$ :

1. Цифровізацію внутрішніх процесів/сервісів університету:

- створення базових інформаційних сервісів, які використовуються у навчальному процесі (мультимедійні екрани для навчальних занять, хмарні технології для зберігання та обміну даними тощо);

- створення цифрової бібліотеки (забезпечує доступ студента або викладача до наукової літератури з будь-яких пристроїв, незалежно від місця знаходження і часу доби) з інструментами наукометричного оцінювання показників наукової роботи та публікаційної активності викладачів і співробітників університету;

- цифровізацію процесів управління, в тому числі, дослідницькими проє- 
ктами, закупівлями, взаємодією з абітурієнтами та студентами тощо;

- створення цифрових кампусів (досвід США, європейських країн).

2. Створення системи цифрового маркетингу, яка б забезпечувала: організацію взаємодії університету з абітурієнтами та їхніми батьками, випускниками і роботодавцями; постійний моніторинг репутації університету та формування позитивного іміджу ЗВО; стимулювання створення нових цифрових спільнот та інновацій на всіх етапах освітнього циклу та ін.

3. Створення системи цифрової взаємодії з абітурієнтами та студентами:

- використання цифрових технологій для інформування абітурієнтів із різних питань освітнього процесу, що важливо як для вітчизняних вступників, так і для потенційних закордонних абітурієнтів;

- використання аналітики для виявлення результатів навчання студентів та їх рейтингування;

- створення системи зворотного зв'язку зі студентами, вивчення їх думок та пропозицій, оцінювання викладачів, якості навчального плану, необхідності тих чи інших освітньо-професійних програм тощо.

4. Заходи, направлені на подолання цифрової нерівності що в умовах цифрової трансформації може призвести до небажаних

- забезпечення доступу до мережі Інтернет;

- формування відповідних цифрових навичок;

- доступ до технічних засобів (комп'ютери, планшети тощо) для малозабезпечених громадян України.

Цифрова трансформація є великим викликом і водночас великим шансом для українських університетів. Ефективно скористатися ним ЗВО зможуть лише за наявності дієвої державної політики, що розроблена, реалізується та удосконалюється згідно із умовами сьогодення та спрямована на посилення конкурентоспроможності та підвищення якості освіти.

Висновки. Отже, державна політика щодо формування якісної системи надання освітніх послуг є основою інтелектуального та матеріального благополуччя держави. Процеси глобалізації, маркетизації та європеїзації вплинули на перехід національної вищої освіти до ринкової економіки та трансформації вищої освіти до потреб ринку праці.

Пандемія COVID-19 поставила нові виклики перед закладами освіти в аспекти дистанційного навчання та цифровізації навчального процесу. Проте, цифрова трансформація є великим викликом і водночас великим шансом для українських університетів посилити свою конкурентоспроможність, залучити додаткові ресурси, оновити IT-інфраструктуру, підвищити якість освіти, зробити iї доступною та такою, яка зможе забезпечити професійний ріст, дозволить успішно просуватися кар'єрними сходами завдяки спрямованості на індивідуалізацію та гнучкість освітнього процесу.

Напрямами подальших досліджень є розробка положень державної політики щодо цифрової трансформації освіти. 


\section{Список використаних джерел:}

1. Арешонков В. С. Цифровізація вищої освіти: виклики та відповіді. Вісник НАПН України. 2020. № 2 (2). С. 1-6.

2. Буйницька О., Варченко-Троценко Л., Грицеляк Б. Цифровізація закладу вищої освіти. Освітологічний дискурс. 2020. № 1 (28). С. 64-79.

3. Вакуленко В. М. Ретроспективний аналіз розвитку вищої освіти в Україні. Духовність особистості: методологія, теорія і практика. 2020. № 3 (96). С. 103 111.

4. Домбровська С. О. Вища освіта в умовах пандемії: сучасні виклики організації освітнього процесу. Реформа освіти в Україні. Інформаційно-аналітичне забезпечення : матеріали міжнар. наук.-практ. конф., м. Київ, 15 жовт. 2020 р. С. 216 218.

5. Про вищу освіту : Закон України від 01.07.2014 p. № 1556-VI. URL: https:// zakon.rada.gov.ua/laws/show/1556-18\#Техt (дата звернення: 15.04.2021).

6. Мосьпан Н. Вища освіта та ринок праці в Україні: десятиліття взаємодії. Освітологічний дискурс. 2021. № 1 (32). С. 20-38.

7. Пастухова Н. Л., Садовниченко Ю. О. Вища освіта України: у пошуках траєкторії розвитку. Інноваційний розвиток вищої освіти: глобальний, європейський та національний виміри змін : матеріали міжнар. наук.-практ. конф., м. Суми 23-24 квіт. 2020 р. С. 23-26.

8. Перекрест M. I. Цифровізація української освіти. URL: http://elib.umsa. edu.ua/bitstream/umsa/14097/1/Perekrest_Tsyfrovizatsiia.pdf_ (дата звернення: 15.04.2021).

9. Петриків В. Періодизація розвитку змісту вищої історичної освіти в Україні (1945-1991). Педагогічні науки: теорія, історія, інноваційні технології. 2016. № 3 (57). C. 412-419.

10. Про схвалення Концепції розвитку цифрової економіки та суспільства України на 2018-2020 роки та затвердження плану заходів щодо іiі реалізації : Розпорядження Кабінет Міністрів України від 17.01.2018 p. № 67-p. URL: https://zakon.rada.gov.ua/laws/show/67-2018-p\#Text (дата звернення: 15.04.2021).

11. Сидоров Г. Цифровой университет: применение цифровых технологий в современных образовательных учреждениях. URL: https:/www.itweek.ru/ digitalization/article/detail.php?ID=192831. (дата звернення: 15.04.2021).

12. Тєтєрєв В. О. Перспективи розвитку технологій дистанційної освіти в Україні. Вісник ЛНУ імені Тараса Шевченка. 2020. № 5 (336). С.146-151.

13. Ткаченко У. Ю. Періодизація розвитку вищої освіти (1991-2019 рр.). Наукові записки кафедри педагогіки. 2020. Вип. 46. С. 53-58.

14. Тоцька О. Л. Концептуальні засади управління розвитком вищої освіти в Україні: трансформація напрямів державної політики. Проблеми інноваційноінвестиційного розвитку. 2020. № 22. С. 64-70. URL: https://evnuir. vnu.edu.ua/bitstream/123456789/17627/1/article_69.pdf (дата звернення: 15.04.2021).

15. Про Національну стратегію розвитку освіти в Україні на період до 2021 року : Указ Президента України № 344/2013 від 25. 07. 2013 p. URL: https://zakon. rada.gov.ua/laws/show/344/2013\#Text (дата звернення: 15.04.2021).

16. Шевченко Л. С. Цифровізація вищої освіти у стратегії розвитку харківського регіону. URL: https://ndipzir.org.ua/wp-content/uploads/2020/ 


\section{References:}

1.Areshonkov, V. S., 2020. Tsyfrovizatsiya vyshchoyi osvity: vyklyky ta vidpovidi. Visnyk NAPN Ukrayiny. № 2 (2). S. 1-6. [Areshonkov, V. S., 2020. Digitization of higher education: challenges and answers. Bulletin of the National Academy of Pedagogical Sciences of Ukraine. № 2 (2). Pp. 1-6.]

2.Buynytska, O., Varchenko-Trotsenko, L., Hrytselyak, B., 2020. Tsyfrovizatsiya zakladu vyshchoyi osvity. Osvitolohichnyy dyskurs. № 1 (28). S. 64-79. [Buynytska, O., Varchenko-Trotsenko, L., Hrytselyak, B., Digitalization of higher education institution. Educational discourse. № 1 (28). Pp. 64-79.]

3.Vakulenko V. M., 2020. Retrospektyvnyy analiz rozvytku vyshchoyi osvity v Ukrayini. Dukhovnist osobystosti: metodolohiya, teoriya i praktyka. № 3 (96). S. 103-111. [Vakulenko, V. M., 2020. Retrospective analysis of the development of higher education in Ukraine. Spirituality of personality: methodology, theory and practice. № 3 (96). Pp. 103 111.]

4.Dombrovska, S. O., 2020. Vyshcha osvita v umovakh pandemiyi: suchasni vyklyky orhanizatsiyi osvitnoho protsesu. Reforma osvity v Ukrayini. Informatsiyno-analitychne zabezpechennya : materialy mizhnar. nauk.-prakt. konf., m. Kyyiv, 15 zhovt. S. 216-218. [Dombrovska, S. O., 2020. Higher education in a pandemic: modern challenges of the educational process. Education reform in Ukraine. Information and analytical support: materials intern. scientific-practical conf., Kyiv, October 15. Pp. 216-218.]

5.Pro vyshchu osvitu : Zakon Ukrayiny vid 01.07.2014 r. № 1556-VI. Available at: https:// zakon.rada.gov.ua/laws/show/1556-18\#Text (Accessed: 15.04.2021). [On higher education: Law of Ukraine of 01.07.2014 № 1556-VI. URL: https: // zakon.rada.gov.ua/laws/show/1556-18\#Text (access date: 15.04.2021).]

6.Mospan, N., 2021. Vyshcha osvita ta rynok pratsi v Ukrayini: desyatylittya vzayemodiyi. Osvitolohichnyy dyskurs. № 1 (32). S. 20-38. [Mospan, N., 2021. Higher education and the labor market in Ukraine: decades of cooperation. Educational discourse. № 1 (32). Pp. 20-38.]

7.Pastukhova, N. L., Sadovnychenko, Y. O., 2020. Vyshcha osvita Ukrayiny: u poshukakh trayektoriyi rozvytku. Innovatsiynyy rozvytok vyshchoyi osvity: hlobalnyy, yevropeyskyy ta natsionalnyy vymiry zmin : materialy mizhnar. nauk.-prakt. konf., m. Sumy 23-24 kvit. S. 23-26. [Pastukhova, N. L., Sadovnichenko, Y. O., 2020. Higher education of Ukraine: in search of the trajectory of development. Innovative development of higher education: global, European and national dimensions of change: materials intern. scientificpractical conf., Sumy, April 23-24. Pp. 23-26.]

8.Perekrest, M. I. Tsyfrovizatsiya ukrayinskoyi osvity. Available at: http://elib.umsa.edu.ua/bitstream/umsa/14097/1/Perekrest_Tsyfrovizatsiia.pdf (Acces sed: 15.04.2021) [Perekrest, M. I. Digitization of Ukrainian education. URL: http: //elib.umsa. edu.ua/bitstream/umsa/14097/1/Perekrest_Tsyfrovizatsiia.pdf (access date: 15.04.2021).]

9.Petrykiv, V., 2016. Periodyzatsiya rozvytku zmistu vyshcho1 istorychno1 osvity v Ukraini (1945-1991). Pedahohichni nauky: teoriya, istoriya, innovatsiyni tekhnolohiyi. № 3 (57). S. 412-419. [Petrykiv, V., 2016. Periodization of the development of the content of higher historical education in Ukraine (1945-1991). Pedagogical sciences: theory, history, innovative technologies. № 3 (57). Pp. 412-419.] 
10. Pro skhvalennya Kontseptsiyi rozvytku tsyfrovoyi ekonomiky ta suspilstva Ukrayiny na 2018-2020 roky ta zatverdzhennya planu zakhodiv shchodo yiyi realizatsiyi : Rozporyadzhennya Kabinet Ministriv Ukrayiny vid 17.01.2018 r. № 67-r. Available at: https://zakon.rada.gov.ua/laws/show/67-2018-r\#Text (Accessed: 15.04.2021). [On approval of the Concept of development of the digital economy and society of Ukraine for 20182020 and approval of the action plan for its implementation: Order of the Cabinet of Ministers of Ukraine dated January 17, 2018 № 67-r. URL: https://zakon.rada.gov.ua/laws/show/67-2018-p\#Text (access date: 15.04.2021).]

11. Sydorov, H. Tsyfrovoy unyversytet: prymenenye tsyfrovykh tekhnolohyy v sovremennykh obrazovatelnykh uchrezhdenyyakh. Available at:: https://www.itweek.ru/ digitalization/article/detail.php?ID=192831. (Accessed: 15.04.2021). [Sidorov, G. Digital University: the use of digital technologies in modern educational institutions. URL: https://www.itweek.ru/ digitalization / article / detail.php? ID = 192831. (appeal date: 15.04.2021).]

12. Tyetyeryev, V. O., 2020. Perspektyvy rozvytku tekhnolohiy dystantsiynoyi osvity v Ukrayini. Visnyk LNU imeni Tarasa Shevchenka. № 5 (336). S. 146-151. [Teterev, V. O., 2020. Prospects for the development of distance education technologies in Ukraine. Bulletin of Taras Shevchenko Lviv National University. № 5 (336). Pp.146-151.]

13. Tkachenko, U. Y., 2020. Periodyzatsiya rozvytku vyshchoyi osvity (19912019 rr.). Naukovi zapysky kafedry pedahohiky. Vyp. 46. S. 53-58. [Tkachenko U. Y., 2020. Periodization of higher education (1991-2019). Scientific notes of the department of pedagogy.. Vip. 46. Pp. 53-58.]

14. Totska, O. L., 2020. Kontseptualni zasady upravlinnya rozvytkom vyshchoyi osvity v Ukrayini: transformatsiya napryamiv derzhavnoyi polityky. Problemy innovatsiyno-investytsiynoho rozvytku. № 22. S. 64-70. Available at: https://evnuir. vnu.edu.ua/bitstream/123456789/17627/1/article_69.pdf (Accessed: 15.04.2021). [Totska, O. L., 2020. Conceptual principles of higher education development management in Ukraine: transformation of public policy. Problems of innovation and investment development. № 22. Pp. 64-70. URL: https: // evnuir. vnu.edu.ua/bitstream/123456789/17627/1/article_69.pdf (access date: 15.04.2021).]

15. Pro Natsionalnu stratehiyu rozvytku osvity v Ukrayini na period do 2021 roku : Ukaz Prezydenta Ukrayiny № 344/2013 vid 25. 07. 2013 r. Available at: https://zakon. rada.gov.ua/laws/show/344/2013\#Text (Accessed: 15.04.2021). [On the National Strategy for the Development of Education in Ukraine for the period up to 2021: Decree of the President of Ukraine № 344/2013 of 25.07.2013 URL: https: // zakon. rada.gov.ua/laws/show/344/2013\#Text (appeal date: 15.04.2021).]

16. Shevchenko, L. S. Tsyfrovizatsiya vyshchoyi osvity u stratehiyi rozvytku kharkivskoho rehionu. Available at: https://ndipzir.org.ua/wp-content/uploads/2020/ 23.01.2020/Tezy_23_01_2020-19.pdf (Accessed: 15.04.2021). [Shevchenko LS Digitization of higher education in the development strategy of the Kharkiv region. URL: https://ndipzir.org.ua/wp-content/uploads/2020/23.01.2020 / Tezy_23_01_2020-19.pdf (access date: 15.04.2021)]. 